\title{
$170 \mathrm{H}$-progesterone rhythms in congenital adrenal hyperplasia
}

\author{
M C YOUNG, J A ROBINSON, G F READ, D RIAD-FAHMY, AND I A HUGHES \\ Department of Child Health and Tenovus Institute, University of Wales College of Medicine, Cardiff
}

SUMMARY Serial blood spot and saliva samples were collected at home by 18 patients being treated for congenital adrenal hyperplasia to determine the circadian rhythm of $170 \mathrm{H}$ progesterone as an index of therapeutic control. There was a strong correlation between the magnitude of the circadian fall and a single morning measurement of the plasma testosterone concentration taken near the time of the $170 \mathrm{H}$-progesterone rhythm samples. Poor control in pubertal girls produced an exaggerated circadian fall in $170 \mathrm{H}$-progesterone concentrations that were raised at all sampling times. Optimal control (plasma testosterone $1.5-2.5 \mathrm{nmol} / \mathrm{l}$ ) was associated with blood spot and salivary $170 \mathrm{H}$-progesterone concentrations at 0800 hours of between $30-70 \mathrm{nmol} / \mathrm{l}$ and $260-1000 \mathrm{pmol} / \mathrm{l}$, respectively, falling thereafter to $<10 \mathrm{nmol} / \mathrm{l}$ and $<150 \mathrm{pmol} / \mathrm{l}$, respectively. Similar results were obtained in prepubertal patients. Nomograms have been constructed to interpret the daily profiles of blood spot or salivary measurements of $170 \mathrm{H}$-progesterone, or both. The analysis of $170 \mathrm{H}$-progesterone circadian rhythms is useful in monitoring treatment in patients with congenital adrenal hyperplasia, particularly those who may be overtreated.

Congenital adrenal hyperplasia is an uncommon disorder that is easily treatable with maintenance courses of steriods. ${ }^{1}$ The aim is to supplement the decreased production of adrenal cortisol with sufficient oral glucocorticoid to suppress excessive androgen secretion and yet permit normal growth and reproduction. ${ }^{2-4}$ This is difficult to achieve for several reasons; though the normal rate of endogenous cortisol production is known, ${ }^{5}$ there is considerable individual variation in the dose of glucocorticoid required to achieve adequate replacement. ${ }^{2}{ }^{6}$ Glucocorticoid preparations vary in their duration of action and there is uncertainty about their potency in congenital adrenal hyperplasia. ${ }^{36}$ The daily dosage regimen is also important. ${ }^{7}$ Glucocorticoids have a narrow therapeutic range so overtreatment readily leads to signs of hypercortisolism. Conversely, undertreatment leads to signs of androgen excess. Both options may ultimately result in diminished adult height. ${ }^{47}$ Clinical indices of control such as growth and pubertal development must be monitored; they change slowly in reponse to alterations in treatment, however, and the effects of inadequate treatment may be irreversible.

Many biochemical indices have been used, ${ }^{8-12}$ but control often remains suboptimal. The value of single random measurements of $170 \mathrm{H}$-progesterone is limited because of the circadian rhythm in the secretion of this steroid. ${ }^{1314}$ Further methods to refine control are needed.

The results of a previous study suggested that the shape of the $170 \mathrm{H}$-progesterone rhythm may be associated with the degree of therapeutic control. ${ }^{6}$ This paper reports the results of the use of multiple blood spot and salivary $170 \mathrm{H}$-progesterone measurements and the results were compared with plasma testosterone measurements, a reliable index of androgen production.

\section{Patients and methods}

Twenty patients aged from $2 \cdot 5$ to 20 years, of whom 15 were female, with congenital adrenal hyperplasia due to 21-hydroxylase deficiency provided data for the study. Blood spot or salivary $170 \mathrm{H}$-progesterone profiles, or both, were accumulated over a three year period from home collection of samples of capillary blood and saliva at $0800,1200,1800$, and 2200 hours, usually on two consecutive weekend days. Blood spots were obtained using an Autolet device and collected onto Guthrie cards that were 
stored at $4^{\circ} \mathrm{C}$ until transferred to the laboratory. A profile represents $170 \mathrm{H}$-progesterone concentrations during one day. The dose of glucocorticoid, given either as hydrocortisone in divided doses or as dexamethasone once daily, was adjusted according to clinical indices of control, as well as single random measurements of plasma 170H-progesterone and testosterone concentrations, and where appropriate, plasma renin activity. Profiles of $170 \mathrm{H}-$ progesterone in two pubertal male patients were excluded from the analysis because of predominant testicular testosterone production at this age. The remaining 12 pubertal female patients and six prepubertal children provided a total of 80 blood spot, and 127 saliva profiles for analysis. Data from several additional incomplete profiles were also included in the analysis where appropriate.

Plasma and salivary $170 \mathrm{H}$-progesterone, ${ }^{15}$ blood spot $170 \mathrm{H}$-progesterone, ${ }^{16}$ and plasma testosterone $^{17}$ concentrations were determined by radioimmunoassay. The results were analysed by nonparametric statistical methods as the data were generally not normally distributed. Methods are stated where appropriate. The descriptive statistics of median and centiles were used as measures of location and scatter, rather than mean and standard deviation. The magnitude of the $170 \mathrm{H}$-progesterone circadian rhythm was calculated as the difference between the maximum and minimum $170 \mathrm{H}-$ progesterone concentrations during the day, and was termed the peak trough fall. The result of each $170 \mathrm{H}$-progesterone profile was compared with the plasma testosterone concentration that had been measured in a morning blood sample collected in clinic held three days after the weekend samples had been collected for measurement of $170 \mathrm{H}$-progesterone concentrations. Data from pubertal female patients and prepubertal children were analysed separately according to the normal testosterone values for these ages-that is $0.3-2.5 \mathrm{nmol} / \mathrm{l}$ and $<0.5 \mathrm{nmol} / \mathrm{l}$, respectively. ${ }^{18-20}$

\section{Results}

All 20 patients showed a circadian rhythm in blood spot and salivary $170 \mathrm{H}$-progesterone concentrations. There was a morning peak and an evening trough that were consistent for each patient on consecutive weekend days. Figures 1 and 2 show the profiles of $170 \mathrm{H}$-progesterone in blood spot and salivary samples in relation to three defined ranges of plasma testosterone concentration: $0 \cdot 3-2 \cdot 5 \mathrm{nmol} / \mathrm{l}$ (normal range for pubertal female patients), 2.6-5.9 $\mathrm{nmol} / \mathrm{l}$ (moderately raised and indicating poor control), and $>6 \mathrm{nmol} / \mathrm{l}$ (severely raised and indicating extremely poor control). The results of the $170 \mathrm{H}-$

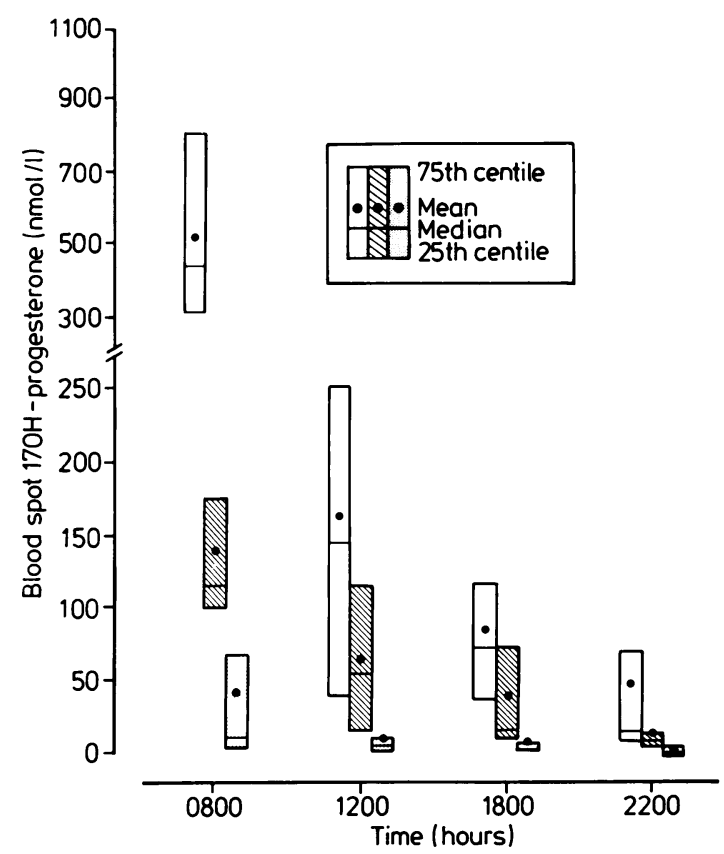

Fig 1 Blood spot 170H-progesterone concentrations and sampling times classified according to range of plasma testosterone concentrations determined in single morning blood sample. Open bars denote testosterone $>6.0$ nmolll, cross hatched bars $2 \cdot 6-5 \cdot 9$, and shaded bars $0 \cdot 3-2 \cdot 5 \mathrm{nmol} / \mathrm{l}$.

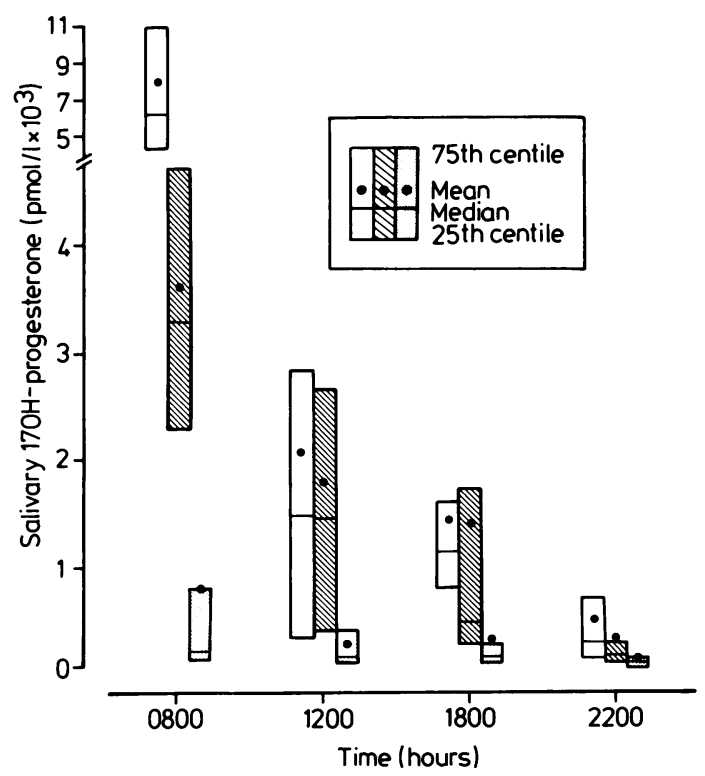

Fig 2 Salivary 170H-progesterone concentration sampling time, and plasma testosterone range. 
Table 1 Blood spot and salivary 170H-progesterone concentrations, sample times, and plasma testosterone concentrations in pubertal girls

\begin{tabular}{|c|c|c|c|c|c|c|c|c|c|c|c|c|}
\hline & \multicolumn{3}{|c|}{ Sampling time (hours) } & \multirow[b]{2}{*}{1200} & \multirow[b]{3}{*}{$T 2$} & \multirow[b]{3}{*}{$T 3$} & \multirow{3}{*}{$\begin{array}{l}1800 \\
T l\end{array}$} & \multirow[b]{3}{*}{$T 2$} & \multirow[b]{3}{*}{$T 3$} & \multirow{3}{*}{$\begin{array}{l}2200 \\
T 1\end{array}$} & \multirow[b]{3}{*}{$T 2$} & \multirow{3}{*}{ T3 } \\
\hline & \multicolumn{3}{|l|}{0800} & & & & & & & & & \\
\hline & $T I$ & $T 2$ & $T 3$ & $T 1$ & & & & & & & & \\
\hline \multicolumn{13}{|l|}{ Blood spot $(\mathrm{nmol} / \mathrm{l})$ : } \\
\hline No of observations & 16 & 12 & 15 & 14 & 12 & 15 & 15 & 12 & 15 & 15 & 11 & 15 \\
\hline Mean & 525 & 140) & 42 & 162 & 67 & 12 & 86 & 40 & 9 & 50 & 10 & 4 \\
\hline Median & 436 & 115 & 10 & 145 & 56 & 5 & 76 & 17 & 5 & 17 & 10 & 3 \\
\hline 25th centile & 312 & 100 & 3 & 40 & 15 & 2 & 38 & 11 & 3 & 10 & 7 & 2 \\
\hline 75 th centile & 811 & 177 & 69 & 253 & 114 & 10 & 118 & 74 & 7 & 71 & 15 & 5 \\
\hline \multicolumn{13}{|l|}{ Saliva $(\mathrm{pmol} / \mathrm{l})$ : } \\
\hline No of observations & 16 & 37 & 30 & 16 & 36 & 30 & 15 & 21 & 25 & 16 & 32 & 28 \\
\hline Mean & 7985 & 3591 & 798 & 2079 & 1783 & 287 & 1439 & 1.387 & 308 & 482 & 308 & 110 \\
\hline Median & 5837 & 3310 & 210 & 1523 & 1478 & 133 & 1120 & 450 & 140 & 285 & 184 & 100 \\
\hline 25 th centile & 4725 & 2324 & 131 & 345 & 415 & 100 & 823 & 275 & 82 & 137 & 115 & 54 \\
\hline 75th centile & 11031 & 4690 & 820 & 2895 & 2635 & 392 & 1620 & 1752 & 262 & 700 & 3() 3 & 1.36 \\
\hline
\end{tabular}

Plasma testosterone $(\mathrm{nmol} / \mathrm{l})$ ranges: $\mathrm{T} 1,>6 \cdot 0 ; \mathrm{T} 2,2 \cdot 6-5 \cdot 9 ; \mathrm{T} 3,0 \cdot 3-2 \cdot 5$.

progesterone measurements have been expressed as mean, median, and interquartile range (25th-75th centiles) (table 1). Blood spot and salivary $170 \mathrm{H}-$ progesterone concentrations in all three groups fell throughout the day being at their lowest by 2200 hours. There was a clear separation between the $170 \mathrm{H}$-progesterone concentrations at each sampling time and for each range of testosterone concentrations. High plasma testosterone concentrations were associated with increased blood spot and salivary $170 \mathrm{H}$-progesterone concentrations $(\mathrm{p}<0.001$ using the Kruskal-Wallis one way analysis of variance). Patients with testosterone concentrations within the

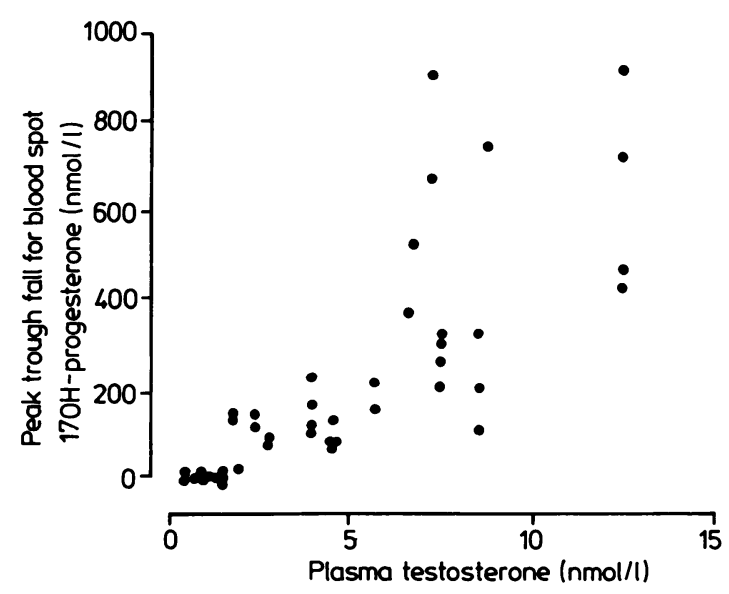

Fig 3 Peak trough fall in blood spot $170 \mathrm{H}$-progesterone concentrations and plasma testosterone concentrations. normal range were clearly separated from the other two groups. Maximum separation occurred when sampling was performed at 0800 hours.

Figures 3 and 4 show the association between peak trough fall and plasma testosterone concentra-

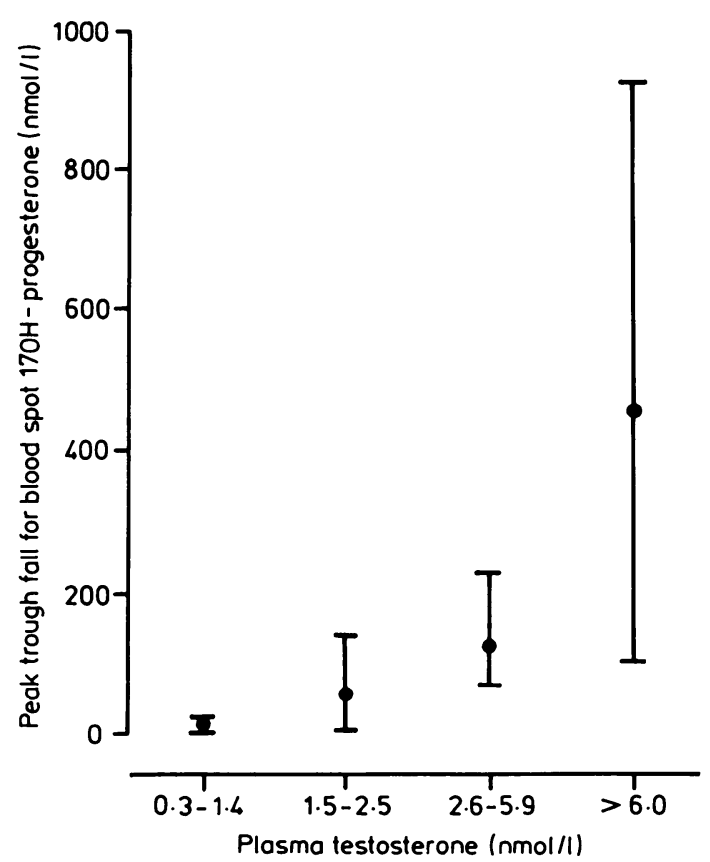

Fig 4 Peak trough fall for blood spot 170H-progesterone values and four ranges of plasma testosterone concentrations. Means, maxima, and minima shown. 
Table 2 Blood spot and salivary 170H-progesterone measurements that differentiate the degree of control in treated congenital adrenal hyperplasia at each sampling time

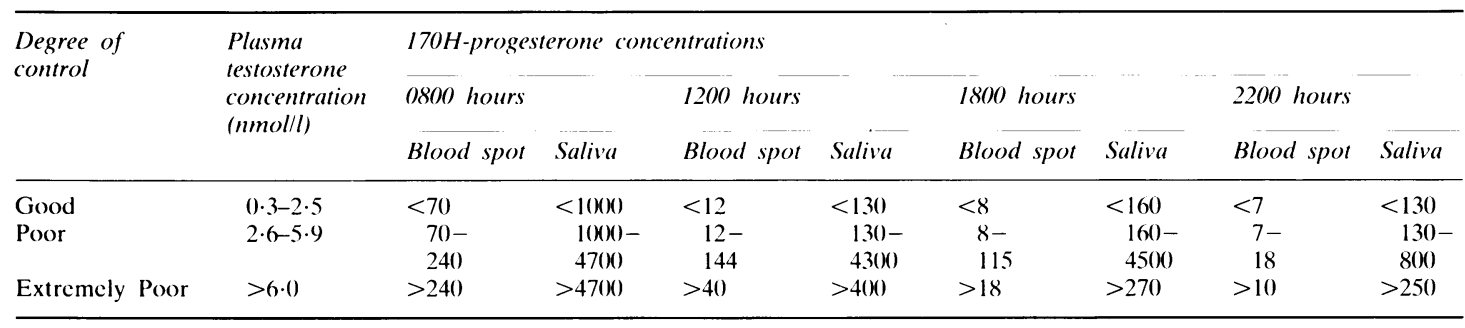

Blood spot 170H-progesterone (nmol/l); saliva 170H-progesterone (pmol/l).

tions. There was a positive correlation indicating that increased testosterone values were associated with a pronounced fall in blood spot $170 \mathrm{H}-$ progesterone concentrations throughout the day. (Spearman's correlation coefficient, $r=0.85$, $\mathrm{p}<0 \cdot 001)$. There was a negligible $170 \mathrm{H}$-progesterone circadian rhythm when plasma testosterone concentrations were low. Similar results were obtained when salivary $170 \mathrm{H}$-progesterone profiles were analysed (unpublished).

Analysis of individual $170 \mathrm{H}$-progesterone values, their ranges, and centile distributions, allowed selection of values for each sampling time that differentiated between the three groups of patients. Table 2 shows the results, which are represented as nomograms in figs 5 and 6 . The blood spot and salivary $170 \mathrm{H}$-progesterone concentrations at 0800 hours were less than $70 \mathrm{nmol} / \mathrm{l}$ and $1000 \mathrm{pmol} / \mathrm{l}$.

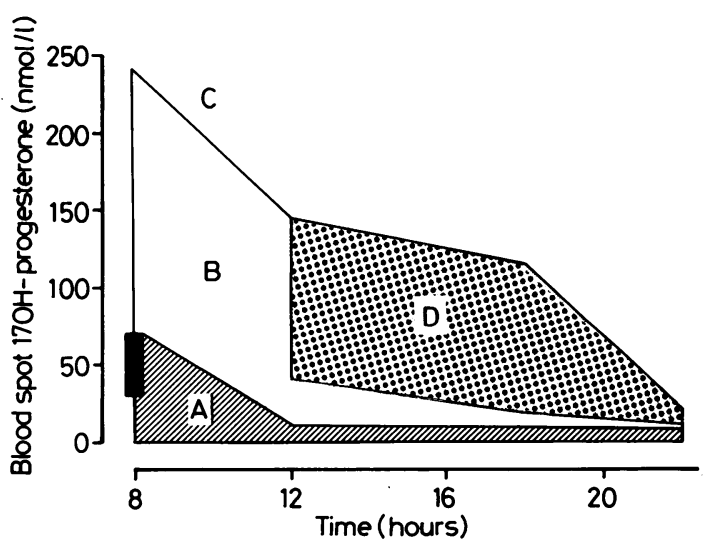

Fig 5 Nomogram to monitor control in congenital adrenal hyperplasia using blood spot $170 H$-progesterone profiles. Labelled areas indicate A: good control; B: poor control; $C$ : extremely poor control; $D$ : area where areas $B$ and $C$ overlap. The shaded bar denotes a $170 \mathrm{H}$-progesterone range of 30-70 nmol/l at 0800 hours which avoids overtreatment.

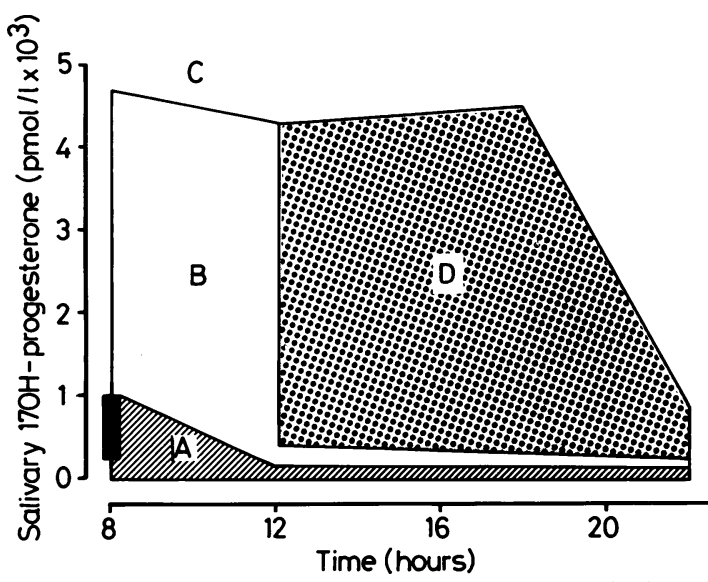

Fig 6 Nomogram to monitor control in congenital adrenal hyperplasia using salivary $170 \mathrm{H}$-progesterone profiles. The shaded bar denotes a $170 \mathrm{H}$-progesterone range of 260-1000 pmolll at 0800 hours. A: good control; B: poor control; C: extremely poor control; $D$ : area where values from $B$ and $C$ overlap.

respectively, when daily $17(0 \mathrm{H}$-progesterone profiles were associated with plasma testosterone concentrations between 0.3 and $2.5 \mathrm{nmol} / \mathrm{l}$. Corresponding values at 1200,1800 , and 2200 hours for blood spot $170 \mathrm{H}$-progesterone (salivary $170 \mathrm{H}$-progesterone) were: $<12(130),<8(160)$, and $<7(130)$. Some of these profiles were found in patients with clinical signs of hypercortisolism. Their $170 \mathrm{H}$-progesterone rhythms were characteristically suppressed or completely abolished together with low peak trough falls. The corresponding testosterone concentrations were significantly lower $(<1.5 \mathrm{nmol} / \mathrm{l})$ than in patients treated adequately $(\mathrm{p}<0.01$; MannWhitney U test). The differences between the two treatment groups are shown in table 3 and fig 4. Profiles of $170 \mathrm{H}$-progesterone with 0800 hour values in the range $30-70 \mathrm{nmol} / \mathrm{l}$ in blood spots and $260-1000 \mathrm{pmol} / \mathrm{l}$ in saliva, decreasing thereafter into the ranges $<10 \mathrm{nmol} / \mathrm{l}$ and $<150 \mathrm{pmol} / \mathrm{l}$, respec- 
Table 3 Comparison of 170H-progesterone profiles and testosterone ranges in over and adequately treated patients

\begin{tabular}{|c|c|c|c|c|c|}
\hline \multirow[t]{3}{*}{$\begin{array}{l}\text { Degree of } \\
\text { control }\end{array}$} & \multirow[t]{3}{*}{ 170H-progesterone profiles } & \multicolumn{2}{|c|}{ Peak trough fall } & \multirow{2}{*}{\multicolumn{2}{|c|}{$\begin{array}{l}\text { Plasma testosterone } \\
\text { (nmol/l) }\end{array}$}} \\
\hline & & \multirow[t]{2}{*}{ Mean } & \multirow[t]{2}{*}{ Range } & & \\
\hline & & & & Mean & Range \\
\hline \multirow[t]{2}{*}{ Overtreated } & Blood spot $(n=10)$ & 3 & $1-16$ & $1 \cdot 1$ & $0 \cdot 3-1 \cdot 4$ \\
\hline & Saliva $(n=23)$ & 283 & - & $1 \cdot 1$ & $0 \cdot 3-1 \cdot 4$ \\
\hline \multirow[t]{2}{*}{ Adequately treated } & Blood spot $(n=5)$ & 111 & $18-112$ & $2 \cdot 1$ & $1 \cdot 5-2 \cdot 5$ \\
\hline & Saliva $(n=8)$ & 1888 & - & $2 \cdot 0$ & $1 \cdot 5-2 \cdot 5$ \\
\hline
\end{tabular}

Peak trough fall nmol/l (blood spot); pmol/1 (saliva).

tively, indicated by shading and marked ' $A$ ' on the nomogram, were associated with plasma testosterone concentrations within the upper part of the normal range for pubertal girls, and no clinical signs of hypercortisolism. Profiles with values below these ranges were associated with overtreatment, despite apparently normal plasma testosterone concentrations.

Five prepubertal patients provided 27 blood spot and 19 salivary $170 \mathrm{H}$-progesterone profiles for analysis. Only six $170 \mathrm{H}$-progesterone profiles (three blood spot and three salivary) were associated with normal plasma testosterone concentrations $(<0) \cdot 5$ nmol/l). Figure 7 shows the relationship between peak trough fall and plasma testosterone concentrations in prepubertal patients; there was a significant positive correlation between the two indices (Pear-

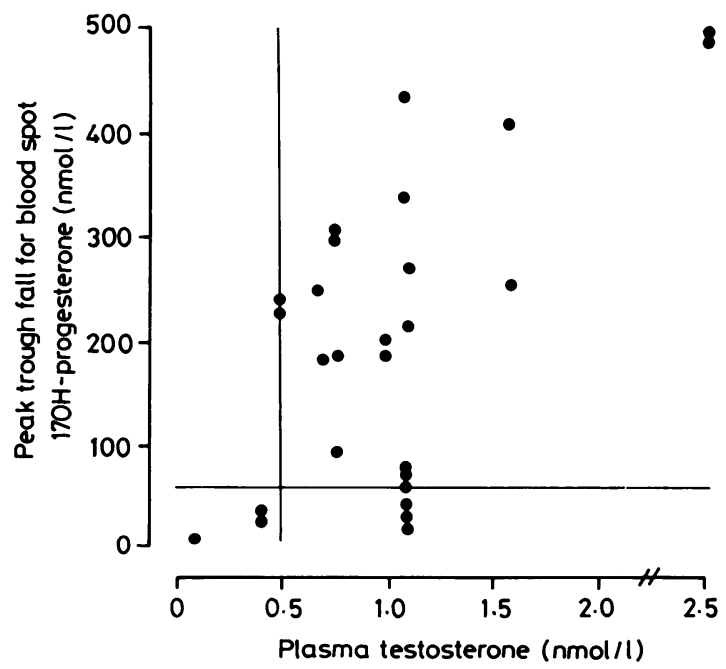

Fig 7 Peak trough fall for blood spot 170H-progesterone values and plasma testosterone concentrations in prepubertal children. Vertical line indicates plasma testosterone concentration of $0.5 \mathrm{nmol} / \mathrm{l}$; horizontal line peak trough fall value of $60 \mathrm{nmol} / \mathrm{l}$. son's correlation $r=0 \cdot 63, p<0 \cdot 001)$. Similar results were obtained when salivary $170 \mathrm{H}$-progesterone profiles were analysed (unpublished data). Figure 7 shows that children with plasma testosterone concentrations of $>0.5 \mathrm{nmol} / \mathrm{l}$ had peak trough fall values above $60 \mathrm{nmol} / \mathrm{l}(1000 \mathrm{pmol} / \mathrm{l}$ when saliva profiles were analysed). These were similar to the peak trough fall values that indicated poor control in pubertal girls (see figs 5 and 6). Consequently the nomograms may be used to interpret $170 \mathrm{H}$ progesterone profiles in prepubertal children though only the two categories of 'good' and 'poor' control can be distinguished.

\section{Discussion}

The circadian rhythm in $170 \mathrm{H}$-progesterone secretion has been shown in plasma, blood spot, and salivary samples. Concentrations of $170 \mathrm{H}$ progesterone were obviously raised in untreated patients with congenital adrenal hyperplasia patients and the circadian rhythm was still maintained. ${ }^{21}$ The rhythm persists after glucocorticoid treatment is started but the magnitude varies according to the degree of therapeutic control. In previous reports the difficulty of using a single, random measurement of $170 \mathrm{H}$-progesterone as an index of control in congenital adrenal hyperplasia has been emphasised. ${ }^{4} 810-12$

Single measurements of plasma testosterone are often used to monitor control in congenital adrenal hyperplasia. They are of limited use as an index of overtreatment because of difficulties with the assay when there are low plasma and salivary concentrations. The predominance of testicular testosterone production in infant and pubertal male patients ${ }^{3}$ further reduces the value of plasma testosterone as a marker of control in congenital adrenal hyperplasia. There is a circadian variation in testosterone values in normal subjects ${ }^{22}$ and in patients with congenital adrenal hyperplasia, ${ }^{14}$ though concentrations do not fluctuate as widely as those of $170 \mathrm{H}$-progesterone.

Increased plasma testosterone concentrations in 
pubertal girls were associated with wide fluctuations in $170 \mathrm{H}$-progesterone concentrations (expressed in this study as the peak trough fall). It was possible from this analysis to define well, poorly, and extremely poorly controlled patients. Similar analysis of the results from prepubertal children defined two groups who were well and poorly controlled. A $170 \mathrm{H}$-progesterone circadian rhythm occurs in normal individuals, untreated patients with congenital adrenal hyperplasia, and treated patients. The rhythm is abolished by excessive glucocorticoid treatment in patients with congenital adrenal hyperplasia. The use of $170 \mathrm{H}$-progesterone profiles provides an accurate index of therapeutic control, and in particular highlights overtreatment with a sensitivity previously unattainable in the management of congenital adrenal hyperplasia. ${ }^{3}$ Signs of hypercortisolism apppear when treatment is designed to achieve $170 \mathrm{H}$-progesterone concentrations within the range for normal individuals. ${ }^{2}$ Profiles of $170 \mathrm{H}$ progesterone obtained from two pubertal male patients during this study showed a similar pattern to that observed in pubertal girls and children. The method may be useful in monitoring control in this group of patients with congenital adrenal hyperplasia.

Measurement of $170 \mathrm{H}$-progesterone is a rapid and reliable test for the diagnosis of congenital adrenal hyperplasia caused by 21-hydroxylase deficiency. ${ }^{810}$ The test has been less acceptable as a reliable marker of control in congenital adrenal hyperplasia. ${ }^{4} 8$ 10-12 Previous studies, however, did not analyse the $170 \mathrm{H}$-progesterone circadian rhythm in patients with congenital adrenal hyperplasia in association with varying degrees of therapeutic control. It is now possible to define all categories of control by reference to the $170 \mathrm{H}$-progesterone nomograms described here. Prospective analysis of $170 \mathrm{H}$-progesterone profiles determined in blood spot and salivary samples shows more than $80 \%$ accuracy in predicting a plasma testosterone value by reference to the nomograms. Inaccurate prediction in the remainder was associated only with the degree of poor control.

Single measurements of $170 \mathrm{H}$-progesterone have commonly been used to monitor treatment in congenital adrenal hyperplasia. This study clearly shows how the practice can provide misleading results. There was an overlap in $170 \mathrm{H}$-progesterone values during the afternoons and evenings in all groups of patients studied. (figs 1 and 2). Even a single $170 \mathrm{H}$-progesterone measurement at 0800 hours may be misleading because some patients may show loss of control only during the latter part of the day. Techniques are now available that determine $170 \mathrm{H}$-progesterone profiles by serial collection of either blood spot or salivary samples. Each type is easy to collect from children. Salivary sampling can be time consuming in infants and is generally disliked by adolescent girls. The use of the $170 \mathrm{H}$ progesterone nomograms now allows fine adjustment to the individual treatment of congenital adrenal hyperplasia at all ages.

\section{References}

New MI, Speiser PW. Genetics of adrenal steroid 21hydroxylase deficiency. Endocr Rev 1986;7:331-49.

2 Huseman CA. Varma MM. Blizzard RM. Johanson A. Treatment of congenital virilizing adrenal hyperplasia patients with single and multiple daily doses of prednisone. $J$ Pediatr 1977:90:538-42.

${ }^{3}$ Hughes IA. Congenital and acquired disorders of the adrenal cortex. J Clin Endocrinol Metab 1982:11:89-97.

+ Hughes IA. Medical and psychological management of congenital adrenal hyperplasia. In: Aynsley-Green A. ed. Paediatric endocrinology in clinical practice. Lancaster: MTP Press. 1983:83-112.

5 Kenny FM, Preeyasombat C, Migeon C.J. Cortisol production rate II. Normal infants, children and adults. Pediatrics 1966:37:34-42.

' Hughes IA. Read GF. Control in congenital adrenal hyperplasia monitored by frequent saliva $170 \mathrm{H}$-progesterone measurements. Horm Res 1984:19:77-85.

7 Winterer J. Chrousos GP. Loriaux DL. Cutler GB. Effect of hydrocortisone dose schedule on adrenal steroid secretion in congenital adrenal hyperplasia. $J$ Pediatr 1985:106:137-42.

${ }^{x}$ Lippe BM, LaFranchi SH, Lavin N, Parlow A, Coyotupa J. Kaplan SA. Serum 17a-hydroxyprogesterone, progesterone, oestradiol, and testosterone in the diagnosis and management of congenital adrenal hyperplasia. J Pediatr 1974:85:782-7.

"McKenna TJ. Jennings AS. Liddle GW. Burr IA. Pregnenolone. 17-OH-pregnenolone and testosterone in plasma of patients with congenital adrenal hyperplasia. J (lin Endocrinol Metab 1976:42:918-25.

11) Korth-Schutz S. Virdis R. Saenger P. Chow DM, Levine LS. New MI. Serum androgens as a continuing index of adequacy of treatment of congenital adrenal hyperplasia. J Clin Endocrinol Metab 1978:46:452-8.

"Hughes IA. Winter JSD. The relationships between serum concentrations of $170 \mathrm{H}$-progesterone and other serum and urinary steroids in patients with congenital adrenal hyperplasia. $J$ Clin Endocrinol Metab 1978:49:98-104.

12 Hughes IA, Read GF. Simultaneous plasma and saliva steroid measurements as an index of control in congenital adrenal hyperplasia (CAH). Horm Res 1982;16:142-50.

1.3 Atherson SM, Barnes ND. Grant DB. Circadian variation in plasma 17-hydroxyprogesterone in patients with congenital adrenal hyperplasia. Arch Dis Child 1972:47:6(12-4.

${ }^{14}$ Frisch H. Parth K. Schober E, Swoboda W. Circadian patterns of plasma cortisol. 17-hydroxyprogesterone. and testosterone in congenital adrenal hyperplasia. Arch Dis Child 1981:56:208-13.

15 Dyas J, Read GF, Guha-Maulik T. Hughes IA. Riad-Fahmy D. A rapid assay for $17 \mathrm{OH}$-progesterone in plasma, saliva and amniotic fluid using a magnetisable solid-phase antiserum. Ann Clin Biochem 1984:21:417-24.

16 Robinson JA, Dyas J, Hughes IA, Riad-Fahmy D. Radioimmunoassay of blood-spot 17a-hydroxyprogesterone in the management of congenital adrenal hyperplasia. Ann Clin Biochem 1987:24:58-65.

17 Dyas J, Read GF. Riad-Fahmy D. A simple robust assay for testosterone in male plasma using an ${ }^{125}$ I-radioligand and a solid-phase separation technique. Ann Clin Biochem 1979:16:325-31. 
is Sizonenko PC. Paunier L. Hormonal changes in puberty III: Correlation of plasma dehydroepiandrosterone, testosterone. FSH, and LH with stages of puberty and bone age in normal boys and girls and in patients with Addisons discase or hypogonadism or with premature or late adrenarche. J Clin Endocrinol Metab 1975:41:894-9()4.

19 Ducharme J-R, Forest MG, De Peretti E, Sempe M, Collu R. Bertrand J. Plasma adrenal and gonadal sex steroids in human pubertal development. $J$ Clin Endocrinol Metab 1976;42:468-76.

20) Korth-Schutz S, Levine L, New MI. Serum androgens in normal prepubertal and pubertal children and in children with precocious adrenarche. J Clin Endocrinol Metab 1976;42:117-24.
21 Solyom J. Diurnal variation in blood 17-hydroxyprogesterone in untreated congenital adrenal hyperplasia. Arch Dis Child 1984;59:743-7.

22 James VHT, Baxendale PM. Androgens in saliva. In: Read GF, Riad-Fahmy D, Walker RF. Griffiths K. eds. Immunoassays of steroids in saliva. Cardiff: Alpha Omega Publishing, 1982; 193-201.

Correspondence to Dr IA Hughes, Department of Child Health, University of Wales College of Medicine, Heath Park, Cardiff CF4 $4 \mathrm{XN}$.

Accepted 15 December 1987 